\title{
Placental corticotrophin-releasing hormone: activator of the pituitary-adrenal axis in human pregnancy?
}

\author{
BY E. A. LINTON ${ }^{1}$, C. D. A. WOLFE ${ }^{2}$ AND P. J. LOWRY ${ }^{1}$ \\ ${ }^{1}$ Departments of Physiology and Biochemistry, University of Reading, Whiteknights, PO Box 228, \\ Reading RG6 $2 A J$ and 'Department of Community Medicine, St Thomas's Hospital, London \\ $S E 17 E H$
}

During pregnancy, the placenta develops into a highly active endocrine organ capable of synthesizing both steroid and protein hormones. Besides pregnancy-specific proteins such as placental lactogen and chorionic gonadotrophin, the placenta contains several hypothalamic hormones (thyrotrophin-releasing hormone (TRH), growth hormonereleasing hormone $(\mathrm{GRH})$, gonadotrophin-releasing hormone $(\mathrm{GnRH})$, corticotrophinreleasing hormone $(\mathrm{CRH})$ ) and also pituitary hormones (adrenocorticotrophin (ACTH), $\beta$-endorphin and $\beta$-lipotrophin), although the placental concentration of these proteins is several orders of magnitude lower than those described for their original sites of production (Krieger, 1982). Of the brain peptides common to the human placenta, CRH is unusual in that it is the most abundant (with $20-30 \mu \mathrm{g} /$ placenta commonplace) as well as being the only neuropeptide that is secreted into the maternal circulation where substantial concentrations are maintained, in contrast to the very low CRH levels found in non-pregnant humans (Linton et al. 1987b). This has led to much speculation as to the physiological significance of placental $\mathrm{CRH}$, especially with regard to its possible role in parturition.

Stress-induced activation of the central nervous system involves the release of CRH, along with other ACTH-secretagogues such as vasopressin, from the hypothalamus. This results in the coordinated control of the hypothalamo-pituitary-adrenocortical (HPA) axis. CRH is a forty-one amino acid peptide (Vale et al. 1981) which, like many neuropeptides and hormones is synthesized as part of a precursor protein, the gene for which has now been identified in the hypothalamus (Shibahara et al. 1983). CRH induces the pituitary corticotrophs to release ACTH, which regulates glucocorticoid synthesis in the cells of the zona fasciculata of the adrenal cortex. The glucocorticoids, among which cortisol predominates in humans, exert a wide range of effects throughout the body, including a negative feedback influence of the synthesis and release of both $\mathrm{CRH}$ and ACTH. With the advent of sensitive and specific immunoassays for CRH, ACTH and total and free cortisol in the $1980 \mathrm{~s}$, it became possible to investigate these stress hormones in both mother and fetus during pregnancy, in an attempt to assess whether placental CRH can modulate the HPA axis.

\section{THE MATERNAL STRESS AXIS}

Following the demonstration of CRH bioactivity (Shibasaki et al. 1982) and immunoreactivity (Sasaki et al. 1984) in extracts of human placentas, several groups have reported the presence of elevated levels of the peptide in maternal peripheral blood during the third trimester of pregnancy (Stalla et al. 1984; Goland et al. 1986; Campbell et al. 1987). In these various studies, a wide range of CRH concentrations has been 
reported and it is thought that the different plasma extraction and immunoassay methods used may account for this discrepancy, together with the demonstration that considerable variation exists in CRH profiles in different women (Campbell et al. 1987). The $\mathrm{CRH}$ concentrations measured in late gestational maternal plasma are similar to the levels reported in rat hypothalamic portal blood and to those capable of stimulating ACTH in vitro. Using an immunoradiometric assay (Linton et al. 1987a), CRH levels were measured and found to rise from a median of $20 \mathrm{pg} / \mathrm{ml}$ at 28 weeks to $1320 \mathrm{pg} / \mathrm{ml}$ at 40 weeks and $1732 \mathrm{pg} / \mathrm{ml}$ during labour. There was a strong correlation $(r 0.81 ; P<0 \cdot 001)$ between gestational age and CRH levels. The rate of rise of $\mathrm{CRH}(\mathrm{pg} / \mathrm{ml})$ per week was associated with weight gain $(r 0.36, P<0.05)$ but with no other obstetric variable (Wolfe et al. $1988 a$ ). The sharp rise in maternal plasma CRH levels up to term is similar to that found for pregnancy-associated plasma protein A (PAPP-A) (Smith et al. 1979) but is unlike most other placental proteins, which plateau in the late third trimester (Bischof $e t$ al. 1982). The small but significant rise in CRH levels between the end of pregnancy and labour is of interest with regard to the possible role of $\mathrm{CRH}$ in the process of parturition. A marked rise of CRH in labour has been reported by Sasaki et al. (1987) but this has not been substantiated by other groups (Laatikainen et al. 1987; Wolfe et al. 1988a). More recently, Petraglia et al. (1990) have demonstrated that plasma CRH increased progressively throughout labour, whilst women undergoing elective caesarean section showed no further change in plasma $\mathrm{CRH}$, suggesting that the increase reflects the stress of labour.

We have also measured maternal plasma $\mathrm{CRH}$ in a range of abnormal pregnancy states (Wolfe et al. 1988b) and significantly elevated levels associated with pregnancyinduced hypertension and preterm labour were found. Levels were raised up to 11 weeks before the onset of preterm labour, again indicating a possible link between CRH and parturition. Furthermore, CRH infusion in fetal sheep has been shown to cause maturation of fetal organs and preterm delivery of the lamb (Wintour et al. 1986). There is also evidence that interleukins which have a possible role in the aetiology of preterm labour (Romero et al. 1989) stimulate placental CRH release in vitro (Petraglia et al. 1987).

Several groups have shown that maternal plasma CRH levels fall precipitously after delivery, returning to normal values within 24 h (Goland et al. 1986, 1990; Campbell et al. 1987; Laatikainen et al. 1987; Sasaki et al. 1987). The rapid clearance of the peptide after delivery would suggest that the placenta is the source of plasma CRH. Further evidence in support of this came with observations that placental $\mathrm{CRH}$, like extracted maternal plasma CRH (Linton et al. 1987b) was biologically and physicochemically identical to synthetic human CRH (Stalla et al. 1986) and that its concentration in the placenta increases with gestational age (Frim et al. 1988). It is now known that the CRH gene is expressed in the human placenta (Grino et al. 1987) and the production of the peptide has been localized to the cytotrophoblast layer (Petraglia et al. 1987; Saijonmaa et al. 1988).

In contrast to the high levels of maternal plasma CRH in the third trimester of pregnancy, plasma ACTH levels remain within the normal non-pregnant range, although increasing slightly with advancing gestation (Rees et al. 1975; Laatikainen et al. 1987; Wolfe \& Linton, 1990) and it is thought that this ACTH also originates from the placenta. A well-documented sharp rise in plasma ACTH then occurs with the stress of labour (Genazzani et al. 1975; Rees et al. 1975; Carr et al. 1981).

Maternal plasma cortisol levels in pregnancy follow a different pattern still: total 


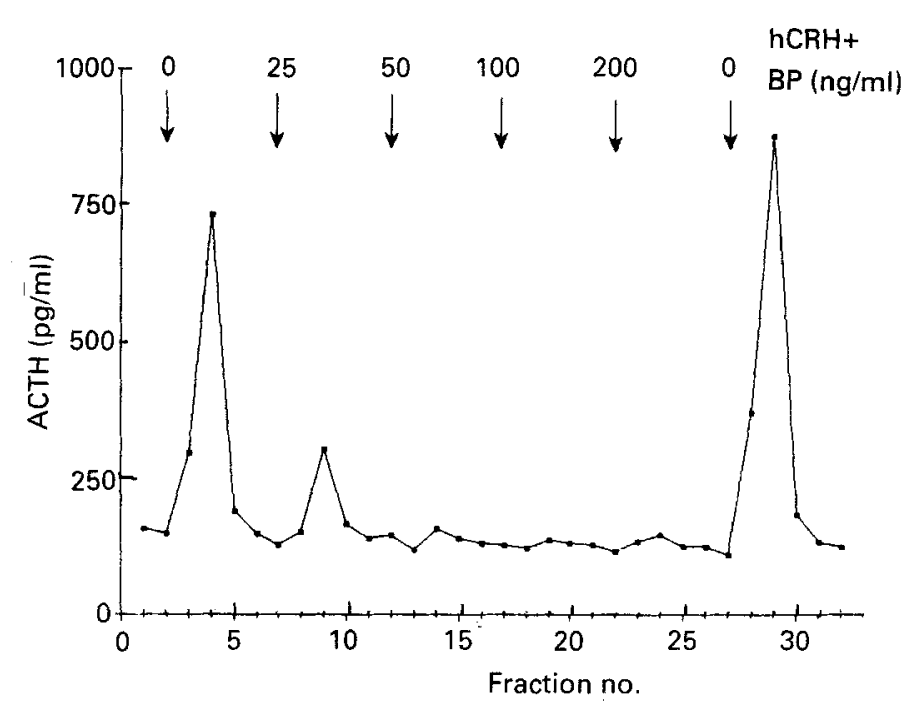

Fig. 1. Effect of corticotrophin-releasing hormone (CRH)-binding protein (BP) on the adrenocorticotrophic hormone (ACTH)-releasing activity of human(h) $\mathrm{CRH}$ after their pre-incubation for $15 \mathrm{~min}$ at $37^{\circ}$. ACTH release in the isolated pituitary cell bioassay is increasingly reduced following exposure to increased concentrations of BP $(25,50,100,200 \mathrm{ng} / \mathrm{ml})$ premixed with a fixed concentration of CRH $(1 \cdot 5 \mathrm{ng} / \mathrm{ml})$.

cortisol increases mainly as a result of the increased cortisol-binding globulin (CBG), a doubling of the cortisol concentration occurring in the first trimester with a twothreefold increase at term (Carr et al. 1981). Plasma free cortisol is the biologically active fraction and several groups have demonstrated a progressive threefold rise from the first to third trimester, although others have shown a significant rise to occur only late in gestation (Rosenthal et al. 1969; Nolten \& Rueckert, 1981; Demey-Ponsart et al. 1982; Allolio et al. 1990).

How then can these changes in $\mathrm{CRH}, \mathrm{ACTH}$ and cortisol throughout pregnancy be explained? It has been shown that most of the $\mathrm{CRH}$ in the maternal circulation is carried by specific CRH-binding protein (CRH.BP) (Linton \& Lowry, 1986; Orth \& Mount, 1987; Linton et al. 1988) and that the CRH-CRH.BP complex has reduced ACTHreleasing activity (see Fig. 1) (Linton et al. 1988, 1990; Suda et al. 1988) which may account for the coexistence of high plasma $\mathrm{CRH}$ alongside marginally increased plasma ACTH. Since cortisol is a well-established negative feedback inhibitor of pituitary ACTH synthesis and secretion and maternal plasma levels of free cortisol are high in the third trimester, it is surprising that ACTH does not remain very low as gestation proceeds. The small rise in plasma ACTH that occurs throughout pregnancy could, therefore, be caused by the small proportion of placental $\mathrm{CRH}$ in maternal plasma that remains free of binding protein. However, in vitro studies with adrenocorticotroph cells have shown that high levels of $\mathrm{CRH}$ are necessary to overcome the negative feedback effect of glucocorticoids (Vale et al. 1983). Alternatively, the small rise in plasma ACTH could result from increasing quantities of placental ACTH which may be released into the peripheral circulation under the paracrine influence of $\mathrm{CRH}$, which has been shown not to be subject to negative feedback by cortisol (Robinson et al. 1988; Jones et al. 
1989). Whether the CRH involved in paracrine ACTH stimulation is protein bound has yet to be ascertained, however. Although the CRH.BP may, in part, explain how elevated plasma CRH coexists with normal plasma $\mathrm{ACTH}$, recent experiments where bolus CRH injections in late pregnancy resulted in a lack of ACTH and cortisol responses in humans (Schulte et al. 1990) or blunted responses in baboons (Goland et al. 1990) point to the existence of additional mechanisms. It is unlikely that bolus administration provides sufficient time for the circulating CRH.BP to complex with the injected $\mathrm{CRH}$, and thus to neutralize its ACTH-releasing activity, especially when one considers that the CRH.BP is also found in non-pregnant women and men (Linton et al. 1988) who react normally to bolus CRH. Additionally, the Goland et al. (1990) study used the ovine $\mathrm{CRH}$ molecule, which differs from the human in seven amino acids and, critically, is not bound by the CRH.BP. However, it is not at present known whether the CRH.BP occurs in the baboon circulation. At least two alternatives have been proposed to explain the lack of response to CRH injection in late pregnancy. First, high levels of placental $\mathrm{CRH}$ may result in desensitization of the $\mathrm{CRH}$ receptors on pituitary corticotrophs, and second, the negative feedback effect of the elevated free cortisol may well be sufficient to blunt the ACTH response to CRH. If indeed this maternal pituitary refractoriness does occur, hypothalamic substances other than CRH (e.g. vasopressin) must be responsible for maintaining the stress response during pregnancy. Evidence that $\mathrm{CRH}$ is not the only mediator of the pituitary-adrenal axis in late pregnancy is also provided by the maintenance of a circadian rhythm in plasma cortisol despite high circulating CRH, which does not itself show any diurnal variation (Schulte et al. 1990).

In summary, then, it is quite possible that all three mechanisms (the CRH.BP, desensitization and down-regulation) operate together in humans to provide a failsafe method whereby placental $\mathrm{CRH}$ release throughout the third trimester is prevented from activating maternal pituitary ACTH secretion. The manner of placental CRH release has not yet been studied, although the gradual increase in plasma CRH in the absence of any major fluctuations (Wolfe et al. 1989) may suggest either a slow, constant or low-level pulsatile release which could allow sufficient time for complex-formation with the CRH.BP to occur. In this case, it is unlikely that placental CRH has any major role in modulating the maternal hypothalamic-pituitary-adrenal axis. However, if the rise in plasma CRH observed during labour occurs as a result of a sudden increase in the pattern of placental $\mathrm{CRH}$ release, secretion of the peptide could well be greater than the rate of CRH-CRH.BP complex formation, leaving sufficient free CRH to activate the pituitaryadrenal axis at parturition. In the light of the existence of the binding protein, then, an endocrine function for placental CRH (in terms of ACTH modulation) would depend on the rate of peptide secretion. It is also possible that placental $\mathrm{CRH}$ has other, as yet unknown, endocrine functions if one considers the possibility that the CRH.BP could act as a delivery system transporting placental $\mathrm{CRH}$ to some peripheral $\mathrm{CRH}$ receptor, e.g. such as has been shown to exist in the immune system (Webster et al. 1989). However, apart from any endocrine action, the peptide is known to exert paracrine influences within the placenta, since in vitro experiments have shown that human placental tissue can secrete CRH, which in turn can induce placental ACTH release (Petraglia et al. 1987; Saijonmaa et al. 1988). Moreover, several substances implicated in parturition including prostaglandins, interleukins, neurotransmitters, peptides and steroids have been shown to modulate CRH release from cultured human placental cells (Jones et al. 1989; Petraglia et al. 1989). 


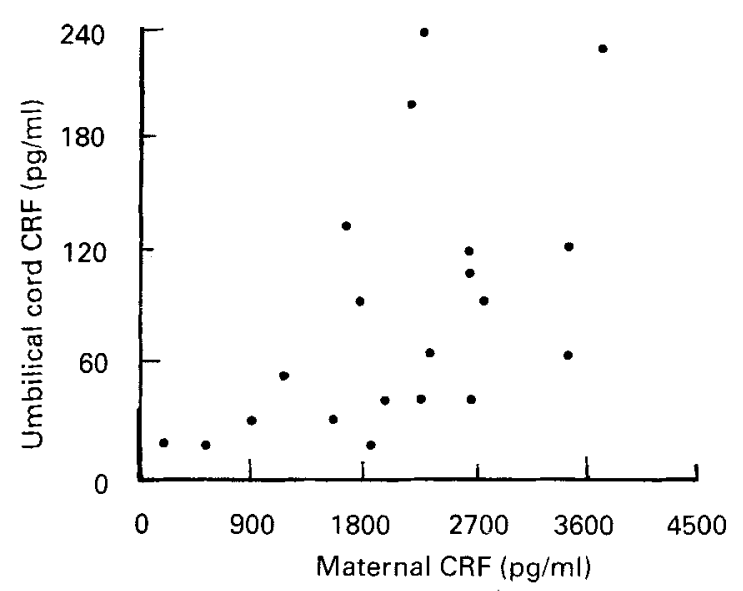

Fig. 2. Correlation between maternal corticotrophin-releasing hormone $(\mathrm{CRH}, \mathrm{pg} / \mathrm{ml})$ and umbilical cord $\mathrm{CRH}(\mathrm{pg} / \mathrm{ml})$ at delivery. Points represent one observation. Correlation $r_{s}(0.54, P<0 \cdot() 1$.

Table 1. Range of maternal and fetal stress-axis hormones

\begin{tabular}{lcc}
\hline \hline & Mother & Fetus \\
\hline Corticotrophin-releasing hormone $(\mathrm{pg} / \mathrm{ml})$ & $31-1262$ & $94-175$ \\
Adrenocorticotrophic hormone $(\mathrm{pg} / \mathrm{ml})$ & $7-135$ & $3-87$ \\
Cortisol (nmol/l) & $135-545$ & $74-324$ \\
\hline
\end{tabular}

\section{THE FETAL STRESS AXIS}

With such dramatic changes occurring in the maternal stress axis, how is the fetus affected? It is thought that the placenta also secretes CRH into the fetal compartment, since $\mathrm{CRH}$ has been demonstrated in umbilical cord plasma at delivery and a close correlation between maternal and fetal CRH levels has been noted by several groups (Goland et al. 1986, 1990; Campbell et al. 1987; Sasaki et al. 1987). Fetal plasma CRH levels are only $3-4 \%$ of those found in the mother, however (see Fig. 2). It is possible that any placental $\mathrm{CRH}$ secreted into the fetal circulation could be involved in the stimulation and maturation of the fetal pituitary-adrenal system. With the advent of cordocentesis as an accepted procedure, access to the profile of stress hormones in the fetus at earlier stages of gestation have now become possible.

Our recent work (Wolfe \& Linton, 1990) has attempted to correlate CRH, ACTH and cortisol in both mother and fetus. Maternal and fetal umbilical blood samples, taken antenatally between 18 and 36 weeks gestation in twenty-four subjects, were examined along with fetal blood gases. The ranges of these stress hormones are displayed in Table 1. There is a significant rise in maternal plasma $\mathrm{CRH}, \mathrm{ACTH}$ and cortisol with gestation age $(P<0 \cdot 05)$, but no significant relationship exists between them. Surprisingly a significant negative correlation of fetal $\mathrm{CRH}$ with gestational age was observed, the opposite relationship to that found in the mother. This falling level of fetal $\mathrm{CRH}$ between 
18-36 weeks gestation occurs at a time when maternal $\mathrm{CRH}$ is rising rapidly and may indicate maturation of the axis, diminishing amounts of CRF being required as pregnancy advances to stimulate the fetal pituitary corticotroph. Fetal ACTH and cortisol do not change significantly. As in the mother, there is no relationship between these hormones in the fetus and no correlation between maternal and fetal axes. In the fetus there is a significant downward trend in $\mathrm{P}_{\mathrm{O}_{2}}, \mathrm{pH}$ and glucose with gestational age and an increase in $\mathrm{P}_{\mathrm{CO}_{2}}$, with no significant trend in lactate, confirming previous findings (Nicolaides et al. 1989). There is no significant correlation between any of these blood gas measurements and the maternal or fetal stress-axis hormones.

These findings are the first to report all the stress-axis hormones and blood gases in both mother and fetus in the third trimester. The numbers are small and some of the pregnancies ended in the delivery of a growth-retarded fetus, but the study indicates the range of concentrations of the various hormones in the maternal and fetal circulation and their changes, if any, with gestational age. Important information is lacking from the window of 35 weeks to term to show how and when fetal plasma CRH rises from the low levels measured at 35-36 weeks to the higher levels reported at delivery. A further crucial question is whether the CRH.BP exists in the fetal circulation in non-saturated quantities. It will be important to investigate this period of gestation for all the stress-axis hormones to confirm or refute the possibility of a fetal stress signal for the onset of parturition.

\section{REFERENCES}

Allolio, B., Hoffman, J., Linton, E. A., Winkelmann, W., Kusche, M. \& Schulte, H. M. (1990). Diurnal salivary cortisol patterns during pregnancy and after delivery; relationship to plasma CRH. Clinical Endocrinology 33, 279-291.

Bischof, P., Duberg, S., Herrmann, W. \& Sizonenko, P. C. (1982). Amniotic fluid and plasma concentrations of pregnancy-associated plasma protein A (PAPP-A) throughout pregnancy; comparison with other feto placental products. British Journal of Obstetrics and Gynaecology 89, 358-363.

Campbell, E. A., Linton, E. A., Wolfe, C. D. A., Scraggs, P. R., Jones, M. T. \& Lowry, P. J. (1987). Plasma CRH concentrations during pregnancy and parturition. Journal of Clinical Endocrinology and Metabolism 64, 1054-1059.

Carr, B. R., Parker, C. R., Madden, J. D., Macdonald, P. C. \& Porter, J. C. (1981). Maternal plasma adrenocorticotrophin and cortisol relationships throughout human pregnancy. American Journal of Obstetrics and Gynecology 139, 416-422.

Demey-Ponsart, E., Foidart, J. M., Sulon, J. \& Sodoyez, J. C. (1982). Serum CBG, free and total cortisol and circadian patterns of adrenal function in normal pregnancy. Journal of Steroid Biochemistry 16, 165-169.

Frim, D. F., Emanuel, R. L., Robinson, B. G., Smas, C. M., Adler, G. K. \& Majzoub, J. (1988). Characterization and gestational regulation of CRH messengerRNA in human placenta. Journal of Clinical Investigation 82, 287-292.

Genazzani, A. R., Fraioli, F., Hurlimann, J., Fioretti, P. \& Felber, J. P. (1975). Immunoreactive ACTH and cortisol plasma levels during pregnancy. Detection and partial purification of corticotrophin-like placental hormone: the human chorionic corticotrophin. Clinical Endocrinology 4, 1-14.

Goland, R. S., Stark, R. I. \& Wardlaw, S. L. (1990). Response to CRH during pregnancy in the baboon. Journal of CXinical Endocrinology and Metabolism 70, 925-929.

Goland, R. S., Wardlaw, S. L., Stark, R. I., Brown, L. S. \& Frantz, A. G. (1986). High levels of CRH immunoreactivity in maternal and fetal plasma during pregnancy. Journal of Clinical Endocrinology and Metabolism 63, 1199-1203.

Grino, M., Chrousos, G. P. \& Margioris, A. N. (1987). The corticotrophin releasing hormone gene is expressed in human placenta. Biochemical and Biophysical Research Communications 148, 1208-1214.

Jones, S. A., Brooks, A. N. \& Challis, J. R. G. (1989). Steroids modulate CRH production in human fetal membranes and placenta. Journal of Clinical Endocrinology and Metabolism 68, 825-830. 
Krieger, D. T. (1982). Placenta as a source of brain and pituitary hormones. Biology of Reproduction 26, 55-71.

Laatikainen, T., Virtanen, T., Raisanen, I. \& Salminen, K. (1987). Immunoreactive CRH and ACTH in plasma during pregnancy, labour and puerperium. Neuropeptides 10, 343-353.

Linton, E. A., Behan, D. P., Saphier, P. W. \& Lowry, P. J. (1990). CRH-binding protein: reduction in the adrenocorticotrophin-releasing activity of placental but not hypothalamic CRH. Journal of Clinical Endocrinology and Metabolism 70, 1574-1580.

Linton, E. A. \& Lowry, P. J. (1986). A large molecular carrier substance for CRF-4I in human plasma. Journal of Endocrinology 111, 150.

Linton, E. A., McLean, F., Nieuwenhuyzen Kruseman, A. C., Tilders, F. J., Van der Veen, E. A. \& Lowry, P. J. (1987a). Direct measurement of human plasma CRH by 'two-site' immunoradiometric assay. Journal of Clinical Endocrinology and Metabolism 64, 1047-1053.

Linton, E. A., Nieuwenhuyzen Kruseman, A. C., Wolfe, C. D. A., Campbell, E. A. \& Lowry, P. J. (1987b). Distribution of immunoreactive CRH in man. Hormone and Metabolic Research 16, Suppl., 38-42.

Linton, E. A., Wolfe, C. D. A., Behan, D. P. \& Lowry, P. J. (1988). A specific carrier substance for human CRF in late gestational maternal plasma which could mask the ACTH-releasing activity. Clinical Endocinology 28, 315-324.

Nicolaides, K. H., Economides, D. L. \& Soothill, P. W. (1989). Blood gases, pH and lactate in appropriate and small for gestational-age fetuses. American Journal of Obstetrics and Gynecology 161, 996-1001.

Nolten, W. E. \& Rueckert, P. A. (1981). Elevated free cortisol index in pregnancy: possible regulatory mechanisms. American Journal of Obstetrics and Gynecology 139, 492-498.

Orth, D. N. \& Mount, C. D. (1987). Specific high affinity binding protein for human CRH in normal human plasma. Biochemical and Biophysical Research Communications 143, 411-417.

Petraglia, F., Giardino, L., Coukos, G., Calza, L., Vale, W. \& Genazzani, A. (1990). CRF and parturition: plasma and amniotic fluid levels and placental binding sites. Obstetrics and Gynaecology 75, 784-789.

Petraglia, F., Sawchenko, P. E., Rivier, J. \& Vale, W. (1987). Evidence for local stimulation of ACTH secretion by CRF in human placenta. Nature 328, 717-719.

Petraglia, F., Sutton, S. \& Vale, W. (1989). Neurotransmitters and peptides modulate the release of immunoreactive CRH from cultured human placental cells. American Journal of Obstetrics and Gynecology 160, 247-251.

Rees, L. H., Burke, C. W., Chard, T., Evans, S. E. \& Letworth, A. T. (1975). Possible placental origin of ACTH in normal human pregnancy. Nature 254, 620-622.

Robinson, B. G., Emanuel, R. L., Frim, D. M. \& Majzoub, J. A. (1988). Glucocorticoid stimulates expression of CRH gene in human placenta. Proceedings of the National Academy of Science, U.S. A. 85, 5244-5248.

Romero, R., Brody, D. T., Oyarzun, E., Mazor, M., Wu, Y. K., Hobbins, J. C. \& Durum, S. K. (1989). Infection and labour. Interleukin 1: a signal for the onset of parturition. American Journal of Obstetrics and Gynecology 160, 1117-1123.

Rosenthal, H. E., Slaunwhite, W. R. \& Sandberg, A. A. (1969). Transcortin: a corticosteroid-binding protein of plasma. X. Cortisol and progesterone interplay and unbound levels of these steroids in pregnancy. Journal of Clinical Endocrinology 29, 352-367.

Saijonmaa, O., Laatikainen, T. \& Wahlstrom, T. (1988). CRF in human placenta: localization, concentration and release in vitro. Placenta 9, 373-385.

Sasaki, A., Liotta, A. S., Luckey, M. M., Margioris, A. N., Suda, T. \& Krieger, D. (1984). Immunoreactive corticotrophin releasing factor is present in human maternal plasma during the third trimester of pregnancy. Joumal of Clinical Endocrinology and Metabolism 59, 812-814.

Sasaki, A., Shinkawa, O., Margioris, A. N., Liotta, A. S., Sato, S., Murakami, O., Meigan, G., Shimizu, Y., Hanew, K. \& Yoshinaga, K. (1987). Immunoreactive CRH in human plasma during pregnancy, labour and delivery. Journal of Clinical Endocrinology and Metabolism 64, 224-229.

Schulte, H. M., Weisner, D. \& Allolio, B. (1990). The CRH test in late pregnancy: lack of adrenocorticotrophin and cortisol response. Clinical Endocrinology 33, 99-106.

Shibahara, S., Morimoto, Y., Furatani, Y., Notake, M., Takahashi, H., Shimizu, S., Horikawa, S. \& Numa, S. (1983). Isolation and sequence analysis of the human corticotrophin-releasing factor precursor gene. EMBO Journal 2, 775.

Shibasaki, T., Odagiri, E., Shizume, K. \& Ling, N. (1982). CRF-like activity in human placental extract. Journal of Clinical Endocrinology and Metabolism 55, 384-386.

Smith, R., Bischof, P., Hughes, G. \& Klopper, A. (1979). Studies on pregnancy-associated plasma protein A in the third trimester of pregnancy. British Journal of Obstetrics and Gynaecology 86, 882-887. 
Stalla, G. K., Bost, H., Kaliebe, T., von Werder, K. \& Muller, O. A. (1986). Human placental CRH is identical to hypothalamic CRH. Acta Endocrinologica 274, Suppl., 169-170.

Stalla, G. K., Hartwimmer, J., von Werder, K. \& Muller, O. A. (1984). Ovine and human CRF in man: CRF stimulation and CRF immunoreactivity. Acta Endocrinologica 106, 289-297.

Suda, T., Iwashita, M., Tozawa, F., Ushiyama, T., Tomori, N., Sumitomo, T., Nakagami, Y., Demura, H. \& Shizume, K. (1988). Characterization of CRH binding protein in human plasma by chemical cross-linking and its binding during pregnancy. Journal of Clinical Endocrinology and Metabolism 67, 1278-1283.

Vale, W., Spiess, J., Rivier, C. \& Rivier, J. (1981). Characterization of a 41-residue ovine hypothalamic peptide that stimulates secretion of corticotropin and $\beta$-endorphin. Science 213, 1394-1397.

Vale, W., Vaughan, J., Smith, M., Yamamoto, G., Rivier, J. \& Rivier, C. (1983). Effects of synthetic ovine $\mathrm{CRH}$, glucocorticoids, catecholamines, neurohypophyseal peptides and other substances on cultured corticotropic cells. Endocrinology 113, 1121-1131.

Webster, E. L., Battaglia, G. \& De Souza, E. B. (1989). Functional CRF receptors in mouse spleen: evidence from adenylate cyclase studies. Peptides 10, 395-401.

Wintour, E. M., Bell, R. J., Carson, R. S., MacIsaac, R. J., Tregear, G. W., Vale, W. \& Wang, X. M. (1986). Effect of long term infusion of ovine CRF in the immature ovine fetus. Journal of Endocrinology 111, $469-475$.

Wolfe, C. D. A. \& Linton, E. A. (1990). Stress signals from the mother, fetus and placenta. Contemporary Reviews in Obstetrics and Gynaecology 2, 1-8.

Wolfe, C. D. A., Patel, S. P., Campbell, E. A., Linton, E. A., Anderson, J., Lowry, P. J. \& Jones, M. T. (1988a). Plasma corticotrophin-releasing factor (CRF) in normal pregnancy. British Journal of Obstetrics and Gynaecology 95, 997-1002.

Wolfe, C. D. A., Patel, S. P., Linton, E. A., Campbell, E. A., Anderson, J., Dornhorst, A., Lowry, P. J. \& Jones, M. T. (1988b). Plasma CRH in abnormal pregnancy. British Journal of Obstetrics and Gynaecology 95, 1003-1006.

Wolfe, C. D. A., Quartero, H. W. P., Carabelli, P., Linton, E. A., Campbell, E. A., Hutt, E., Achtereekte, H. \& Lowry, P. J. (1989). Variation of maternal plasma CRF in pregnancy and labour. Journal of Gynaecological Endocrinology 4, 15-18. 